BOGDAN WALCZAK

Akademia im. Jakuba z Paradyża w Gorzowie Wielkopolskim

ORCID: 0000-0001-8293-0188

\title{
W labiryncie polszczyzny. Profesorowi Stanislawowi Dubiszowi - doktorzy $i$ doktoranci, pod redakcją Beaty Karoliny Jędryki i Eweliny Kwapień. Dom Wydawniczy „Elipsa”, Warszawa 2017, ss. 393
}

Z okazji 45-lecia pracy prof. Stanisława Dubisza na Uniwersytecie Warszawskim Jego uczniowie, doktorzy i doktoranci (a doktorów wypromował prof. Dubisz w ciągu tych 45 lat aż 20, po roku 2000 także spośród studiujących w Polsce [głównie Białorusinów i Ukraińców] stypendystów rządu RP; są wśród nich tak znani już badacze, jak Halina Karaś, Małgorzata Majewska, Kinga Geben, Izabela Winiarska-Górska, Ewelina Kwapień itd.), ofiarowali swojemu Mistrzowi piękny tom, który jeden z recenzentów wydawniczych, prof. Bogusław Nowowiejski, określił mianem „udanego przedsięwzięcia wydawniczego" (z fragmentu przedrukowanego na czwartej stronie okładki).

Prace odzwierciedlają oczywiście obszary badań uprawiane przez uczniów prof. S. Dubisza, a pierwotnie, rzecz jasna, przez Niego samego, gdyż to On decydował o tematyce ich prac doktorskich, a potem nierzadko wpływał na ich dalsze badania. Stąd redaktorkom tomu udało się zgrabnie uporządkować złożone do tomu artykuły. Sytuują się one ostatecznie w kilku działach, związanych z głównymi kierunkami działalności naukowej Stanisława Dubisza: Język - historia - kultura, Język polski poza granicami kraju, Język polski w szkole i $Z$ różnych obszarów badawczych: dialektologia - wymowa - stylizacja. Język polski za granicą i w szkole obejmuje pod względem geograficznym bardzo rozległe terytorium od Brazylii, Kanady i Stanów Zjednoczonych na zachodzie po Litwę, Białoruś, Ukrainę i Rosję na wschodzie. Gdy chodzi o artykuły usytuowane w dziedzinie dialektologii i zagadnień stylizacyjnych, godzi się przypomnieć, że prof. S. Dubisz rozpoczynał swoją imponującą karierę naukową jako dialektolog (badacz słownictwa gwar ostródzkich, warmińskich i mazurskich), a ogólnosłowiański (przynajmniej) rozgłos zyskał jako badacz stylizacji gwarowej (w prozie powojennej) i archaizacji ( $\mathrm{w}$ dwudziestowiecznej powieści historycznej o średniowieczu). Wreszcie związki języka, historii i kultury to główny kierunek badań prof. S. Dubisza jako - prymarnie - historyka języka polskiego.

$\mathrm{Na}$ koniec oddajmy jeszcze głos redaktorkom tomu (potwierdzającym tutaj niektóre wyrażone wyżej intuicje): „Ze względu na wszechstronny i bardzo różnorodny 
zakres badań Profesora Stanisława Dubisza, Jego seminaria cieszyły się zawsze dużym zainteresowaniem ze strony słuchaczy, którzy pod Jego opieką prowadzili własne badania naukowe. Tematyka prac uczniów Profesora [...] odzwierciedla zatem również Jego własne pasje.

1 października 1972 roku Profesor Stanisław Dubisz rozpoczął pracę na Wydziale Polonistyki. W tym roku mija więc 45 lat Jego pracy na Uniwersytecie Warszawskim i z tej okazji postanowiliśmy opublikować zbiorowy tom autorstwa wypromowanych przez Niego doktorów oraz doktorantów. Podobnie jak zainteresowania naukowe Profesora Stanisława Dubisza, tak i zgromadzone tutaj teksty są niezwykle różnorodne - dlatego też jedynym odpowiednim tytułem, który tę wielowątkowość mógł objąć, jest tytuł W labiryncie polszczyzny" (s. 9).

Niniejsza zwięzła prezentacja nie wyklucza szczegółowej merytorycznej recenzji, na którą tom ze wszech miar zasługuje (niezależnie od raczej kokieteryjnej deklaracji: „Prosimy o wyrozumiałość podczas lektury przygotowanych przez nas artykułów. Nie mogliśmy przecież pokazać ich naszemu Nauczycielowi i Mistrzowi, nie są zatem zapewne wolne od uchybień i niedociągnięć” [s. 11]). 